\title{
An exploration investigation on the role of industrial market information on the success of negotiations
}

\author{
Homeyra Zare and Somayeh Hozouri*
}

Department of Management, Islamic Azad University, South Tehran Branch, Tehran, Iran

\section{H R O N I C L E}

Article history:

Received June 10, 2013

Received in revised format

25 August 2013

Accepted September 262013

Available online

October 152013

Keywords:

Information technology

Factor analysis

Negotiation \begin{abstract}
A B S T R A C T
Information plays an important role on having crystal clear image about market. A good awareness about products, vendors, new rivals, etc. always helps us offer better prices and reach better agreements. This paper presents an investigation on the role of industrial market information on the success of negotiations. The proposed study designs a questionnaire in Likert scale consists of 22 questions, distributes it among 228 Iranian experts and analyzes it based on principal component analysis. During the survey, the numbers of questions are reduced to 17. Cronbach alpha is calculated as 0.86 and Kaiser-Meyer-Olkin Measure of Sampling Adequacy and Approx. Chi-Square are 0.773 and 745.8 , respectively. Based on the results of our survey, we have derived six factors including human resource management, integrated strategy, organizational software packages, communication factors, penetration factors, past perception and assessment process.
\end{abstract}

\section{Introduction}

Growing globalization and environmental uncertainty have increased the challenges we face in offering goods or services. Integration of necessary information systems across partnering firms has become the backbone of supply chain management (SCM), since it facilitates the sharing of information needed to enhance organizational flexibility and responsiveness while minimizing unwelcome risk and inventory expenses. Rajaguru and Matanda (2012) studied the effect of interorganizational information system (IOIS) integration on the association between inter-organizational compatibility and supply chain capabilities based on data collected from the Australian retailing sectors. They reported that inter-organizational compatibility of technical, strategic, and cultural inter-organizational dimensions could facilitate IOIS integration and supply chain capabilities. They also suggested that to reach maximum advantages for all chain members, IOIS integration requires to be embedded in the strategies and objectives of partnering organizations. Business-to-business and industrial marketing managers have to be informed that IOIS integration processes need support of top managers of the partnering firms and should be embedded in the organizations' strategic objectives.

* Corresponding author. Tel.: +98 912536-7924

E-mail addresses: saho84@rocketmail.com (S. Hozouri)

(C) 2014 Growing Science Ltd. All rights reserved. doi: $10.5267 /$ j.uscm.2013.10.003 
Beynon-Davies, P. (2009) provided a more detailed account of the concept of an information system (IS) (Besson \& Rowe, 2012) and established the idea of an IS as a semi-formal 'language' necessary for the coordination and control of activity in different forms of human organization. Lin and Hong (2009) proposed a marketing IS for a Tea-beverage manufacturing business unit for supporting sales management. The marketing information system concentrates at providing assistance in performing efficient dissemination and management of necessary data and sales documents as well as improving marketing and promotion processes. They reported that their proposed model could provide better support for managers as a result of improved communication and monitoring. Strategic Information Systems Planning (SISP) plays an essential role for better management of different systems.

Teubner (2007) performed an investigation in a German financial services company (FSC) and studied the enterprise situation and the information system practices situation of FSC based on the SISP approach in place. They reported that practitioners largely ignore academic literature and did not implement it in support of their SISP efforts. Buhl et al. (2012) performed an investigation to find where the competitive advantage in strategic information systems research could be more detected by performing a survey on the German business and information systems engineering tradition.

Li et al. (2008) developed a research model of initial trust formation by considering different factors such as trusting bases, trusting beliefs, trusting attitude and subjective norm, and trusting intentions. They made an assessment on eight trusting base factors including personality, cognitive, calculative, and both technology and organizational factors of the institutional base. They reported that subjective norm and the cognitive-reputation, calculative, and organizational situational normality base factors substantially impact initial trusting beliefs and other downstream trust constructs.

Konchitchki and O'Leary (2011) investigated the use of event studies in information systems and accounting information systems research based on a three-pronged approach. First, they provided a comprehensive survey of the existing research about announcements of the adoption of enterprise resource planning systems and of the impact of security breaches in firms' information systems. Next, they summarized event study methodologies applied in prior research, along with some of the key parameters and concerns associated with their implementation and provided shed light on key event study modeling issues.

Järveläinen (2013) presented a framework for business continuity management, and extended it to the IS context. They also validated the method in a survey of IT managers and chief information officers in some organizations operating in Finland. They reported that social factors such as committed managers and employees were influential in decreasing negative business impacts.

\section{The proposed study}

This paper presents an investigation on the role of industrial market information on the success of negotiations. The proposed study designs a questionnaire in Likert scale consists of 22 questions, distributes it among 228 Iranian experts and analyzes it based on principal component analysis. During the survey, the numbers of questions are reduced to 17. Cronbach alpha is calculated as 0.86 and Kaiser-Meyer-Olkin Measure of Sampling Adequacy and Approx. Chi-Square are 0.773 and 745.8, respectively. Fig. 1 demonstrates the results of Scree plot. As we can observe from the results of Fig. 1, there are two factors, which could be extracted for further studies. In addition, as we can observe from the results of communalities given in Table 1 , most factors are well above the minimum acceptable level of 0.5 . Table 2 demonstrates the results of factor analysis on these factors. 


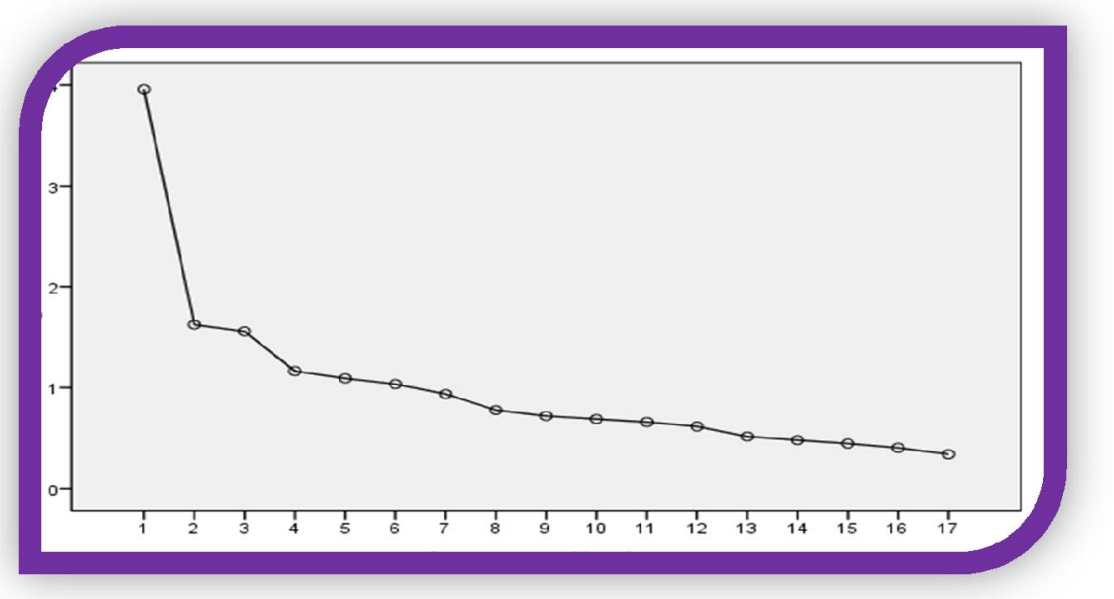

Fig. 1. The summary of Scree plot

Table 1

The summary of communalities

\begin{tabular}{|c|c|c|}
\hline & Initial & Extraction \\
\hline VAR00001 & 1.000 & .694 \\
\hline VAR00002 & 1.000 & .654 \\
\hline VAR00003 & 1.000 & .563 \\
\hline VAR00004 & 1.000 & .680 \\
\hline VAR00005 & 1.000 & .603 \\
\hline VAR00007 & 1.000 & .474 \\
\hline VAR00008 & 1.000 & .684 \\
\hline VAR00009 & 1.000 & .533 \\
\hline VAR00010 & 1.000 & .709 \\
\hline VAR00011 & 1.000 & .555 \\
\hline VAR00012 & 1.000 & .573 \\
\hline VAR00013 & 1.000 & .582 \\
\hline VAR00014 & 1.000 & .560 \\
\hline VAR00015 & 1.000 & .645 \\
\hline VAR00016 & 1.000 & .738 \\
\hline VAR00017 & 1.000 & .552 \\
\hline VAR00019 & 1.000 & .632 \\
\hline
\end{tabular}

Table 2

The summary of principal component analysis after rotation

\begin{tabular}{|c|c|c|c|c|c|c|c|c|c|}
\hline \multirow[t]{2}{*}{ Component } & \multicolumn{3}{|c|}{ Initial Eigenvalues } & \multicolumn{3}{|c|}{ Extraction Sums of Squared Loadings } & \multicolumn{3}{|c|}{ Rotation Sums of Squared Loadings } \\
\hline & Total & $\%$ of Variance & $\begin{array}{l}\text { Cumulative } \\
\%\end{array}$ & Total & $\begin{array}{l}\% \text { of } \\
\text { Variance }\end{array}$ & $\begin{array}{l}\text { Cumulative } \\
\%\end{array}$ & Total & $\begin{array}{l}\% \text { of } \\
\text { Variance }\end{array}$ & $\begin{array}{l}\text { Cumulative } \\
\%\end{array}$ \\
\hline 1 & 3.960 & 23.291 & 23.291 & 3.960 & 23.291 & 23.291 & 2.593 & 15.250 & 15.250 \\
\hline 2 & 1.625 & 9.559 & 32.850 & 1.625 & 9.559 & 32.850 & 1.942 & 11.425 & 26.676 \\
\hline 3 & 1.558 & 9.166 & 42.016 & 1.558 & 9.166 & 42.016 & 1.549 & 9.110 & 35.785 \\
\hline 4 & 1.164 & 6.846 & 48.862 & 1.164 & 6.846 & 48.862 & 1.510 & 8.884 & 44.670 \\
\hline 5 & 1.092 & 6.422 & 55.284 & 1.092 & 6.422 & 55.284 & 1.453 & 8.545 & 53.214 \\
\hline 6 & 1.034 & 6.084 & 61.368 & 1.034 & 6.084 & 61.368 & 1.386 & 8.154 & 61.368 \\
\hline 7 & .935 & 5.503 & 66.871 & & & & & & \\
\hline 8 & .776 & 4.567 & 71.438 & & & & & & \\
\hline 9 & .718 & 4.222 & 75.660 & & & & & & \\
\hline 10 & .688 & 4.047 & 79.708 & & & & & & \\
\hline 11 & .658 & 3.868 & 83.576 & & & & & & \\
\hline 12 & .614 & 3.612 & 87.187 & & & & & & \\
\hline 13 & .514 & 3.025 & 90.213 & & & & & & \\
\hline 14 & .478 & 2.813 & 93.026 & & & & & & \\
\hline 15 & .444 & 2.613 & 95.639 & & & & & & \\
\hline 16 & .402 & 2.367 & 98.007 & & & & & & \\
\hline 17 & .339 & 1.993 & 100.000 & & & & & & \\
\hline
\end{tabular}


Based on the results of our survey, we have derived six factors including human resource management, integrated strategy, organizational software packages, communication factors, penetration factors, past perception and assessment process.

\section{The results}

In this section, we present details of our findings on six influencing factors.

\subsection{The first factor: Human resource management}

The first factor is associated with human resource management. Table 3 demonstrates details of our study. As we can observe from the results of Table 3, "Organizational change" is the most important factor, followed by "Good quality input data", "Taking advantage of information technology", and "Using electronic business".

\section{Table 3}

The summary of factors associated with human resource management

\begin{tabular}{|c|c|c|c|c|}
\hline Option & Factor & Eigenvalues & $\%$ of variance & Accumulated \\
\hline Good quality input data & 0.652 & & & \\
\hline Organizational change & 0.727 & 2.489 & 62.223 & 62.223 \\
\hline Using electronic business & 0.577 & & & \\
\hline Taking advantage of information technology & 0.578 & & & \\
\hline
\end{tabular}

\subsection{The second factor: Integrated software packages}

Integrated software packages are the second important issues and they include two factors, which are summarized in Table 4 as follows,

\section{Table 4}

The summary of factors associated with integrated software packages

\begin{tabular}{lcccc}
\hline Option & Factor & Eigenvalues & \% of variance & Accumulated \\
\hline Resource management program & 0.502 & & & \\
Automation & 0.806 & 2.031 & 50.767 & 50.767 \\
\hline Cronbach alpha $=0.87$
\end{tabular}

According to the results of Table 4, "Automation" is number one priority followed by "Resource management program".

\subsection{The third factor: Communication factors}

Communication factors are the third important issues and they include three factors, which are summarized in Table 5 as follows,

\section{Table 5}

The summary of factors associated with communication factors

\begin{tabular}{lcccc}
\hline Option & Factor & Eigenvalues & \% of variance & Accumulated \\
\hline Firm expenses & 0.863 & & & 69.782 \\
Information & 0.863 & 2.093 & 69.782 & 69.782 \\
Management of information & 0.778 & & & \\
\hline
\end{tabular}

Cronbach alpha $=0.88$ 
According to the results of Table 5, "Information" is number one priority followed by "firm expenses" and "Management of information".

\subsection{The fourth factor: Penetration factors}

Penetration factors are the fourth important issues and they include three factors, presented in Table 5 as follows,

\section{Table 6}

The summary of factors associated with penetration factors

\begin{tabular}{lcccc}
\hline Option & Factor & Eigenvalues & \% of variance & Accumulated \\
\hline Dangers of hackers & 0.863 & & & \\
Information lost & 0.863 & 1.530 & 38.238 & 38.238 \\
Internet usage & 0.778 & & & \\
\hline
\end{tabular}

Cronbach alpha $=0.40$

According to the results of Table 6, "Information lost" is number one priority followed by "Danger of hackers" and "Internet usage".

\subsection{The fifth factor: Past perception}

Past perception is another factor with two sub-components, presented in Table 7 as follows,

Table 7

The summary of factors associated with past perception

\begin{tabular}{lcccc}
\hline Option & Factor & Eigenvalues & \% of variance & Accumulated \\
\hline Mutual trust between two parties & 0.750 & & & 57.625 \\
\hline Firm reputation & 0.866 & 1.729 & 57.625 & 57.625 \\
\hline
\end{tabular}

Cronbach alpha $=0.63$

According to the results of Table 7, "Firm reputation" is number one priority followed by "Mutual trust between two parties".

\subsection{The sixth factor: Process based approach}

Process based approach is the last factor with two sub-components, presented in Table 8 as follows,

\section{Table 8}

The summary of factors associated with past perception

\begin{tabular}{lcccc}
\hline Option & Factor & Eigenvalues & \% of variance & Accumulated \\
\hline Inter-department communication & 0.857 & 1.424 & 47.476 & 47.476 \\
Competitive advantage & 0.824 & & & \\
\hline Cronbach alpha $=0.49$ & & & &
\end{tabular}

According to the results of Table 8, "Inter-department communication" is number one priority followed by "Competitive advantage".

\section{Conclusion}

This paper has presented an investigation on the role of industrial market information on the success of negotiations. The proposed study of this paper has extracted six factors by applying principal component analysis. The first factor, human resources management, includes four sub-components 
where "Organizational change" is the most important factor, followed by "Good quality input data", "Taking advantage of information technology", and "Using electronic business". The second factor, integrated software packages, maintains two factors where "Automation" is number one priority followed by "Resource management program". The third factor is associated with communication issues where "Information" is number one priority followed by "firm expenses" and "Management of information". The next factor is related to past perception where "Firm reputation" is number one priority followed by "Mutual trust between two parties". Finally, process based approach is the last item where "Inter-department communication" is number one priority followed by "Competitive advantage".

\section{Acknowledgment}

The authors would like to thank the anonymous referees for their construction comments on earlier version of this work.

\section{References}

Beynon-Davies, P. (2009). The 'language'of informatics: The nature of information systems. International Journal of Information Management, 29(2), 92-103.

Besson, P., \& Rowe, F. (2012). Strategizing information systems-enabled organizational transformation: A transdisciplinary review and new directions.The Journal of Strategic Information Systems, 21(2), 103-124.

Buhl, H. U., Fridgen, G., König, W., Röglinger, M., \& Wagner, C. (2012). Where's the competitive advantage in strategic information systems research? Making the case for boundary-spanning research based on the German business and information systems engineering tradition. The Journal of Strategic Information Systems, 21(2), 172-178.

Järveläinen, J. (2013). IT incidents and business impacts: Validating a framework for continuity management in information systems. International Journal of Information Management.

Konchitchki, Y., \& O'Leary, D. E. (2011). Event study methodologies in information systems research. International Journal of Accounting Information Systems, 12(2), 99-115.

Li, X., Hess, T. J., \& Valacich, J. S. (2008). Why do we trust new technology? A study of initial trust formation with organizational information systems. The Journal of Strategic Information Systems, 17(1), 39-71.

Lin, C., \& Hong, C. (2009). Development of a marketing information system for supporting sales in a Tea-beverage market. Expert Systems with Applications,36(3), 5393-5401.

Rajaguru, R., \& Matanda, M. J. (2012). Effects of inter-organizational compatibility on supply chain capabilities: Exploring the mediating role of inter-organizational information systems (IOIS) integration. Industrial Marketing Management, 42(4), 620-632.

Teubner, R. A. (2007). Strategic information systems planning: A case study from the financial services industry. The Journal of Strategic Information Systems, 16(1), 105-125. 